Yayın Geliş Tarihi: $\quad$ 13.09.2017

Yayın Kabul Tarihi: 05.02 .2018

Online Yayın Tarihi: 20.04 .2018
Dokuz Eylül Üniversitesi

Iktisadi ve İdari Bilimler Fakültesi Dergisi

Cilt:32, Sayl:2, Yll:2017, ss. 129-161

\title{
Mobbing İle Mücadelede Farklılıkların Yönetimi Stratejileri
}

\section{Famil MAJIDLi ${ }^{*}$}

\author{
Gönül BUDAK ${ }^{2}$
}

\begin{abstract}
$\ddot{O} \mathbf{z}$
1980'li yullardan itibaren işletme yönetimi çerçevesinde kilit noktalardan biri olan farklllikların yönetimi ve mobbing konuları ile ilgili Türkçe literatürde eksikliğe bağlı olarak bu her iki konuda farkındalı yaratmayı amaçlayan çalışmada çeşitli bilimsel araştırmalara dayanarak yapılmış literatür taraması sonucunda işletme içerisinde uygulanabilecek mobbingle mücadele ve farklllikların yönetimi stratejilerine yer verilmiştir.

Çalışmanın temel bulguları Gilbert vd. tarafindan gelişstirilmiş "Bütünleştirilmiş Etkili Farkllllk Yönetimi Modeli" ve Avusturalya, Yeni Zelanda ve Türkiye hükumetleri tarafindan yayımlanan mobbingle mücadele konulu bildirilerde geliştirilmiş politikalara dayanmaktadır. Bu çalışma kendi bünyesinde farklı özelliklere sahip çalışanları barındıran işletmelere sağllklı örgüt ikliminin oluşturulmasına yönelik kuramsal bir altyapı hazırladığı için önemlidir.
\end{abstract}

Anahtar Kelimeler: Farklllıkların Yönetimi, Mobbing, Isşletme Yönetimi.

JEL Sinfflandırma Kodları: M12, M14.

\section{Diversity Management Strategies In The Prevention Of Mobbing}

The study, which aims to raise awareness about diversity management and mobbing depending upon the lack of academic resources related to these two topics in Turkish literature which have been one of the essential topics within the scope of business management since 1980 's, includes diversity management and mobbing - prevention strategies based on different academic studies throughout literature review.

The main findings of the study based upon Gilbert et al.'s "A Model of Effective Diversity Management" and policies and practices, which are indicated in the report of Australian, New Zealand and Turkish governments and determine strategies about prevention of mobbing. This study is important because it sets up a theoretical background in order to create healthy organizational climate and culture in organizations which hire employees from different cultures, religions, ehtnics, races etc.

Keywords: Diversity Management, Mobbing, Business Management.

JEL Classification Codes: M12, M14.

* Dokuz Eylül Üniversitesi, Sosyal Bilimler Enstitüsü, İşletme Anabilim Dalı, Yüksek Lisans Öğrencisi, mecidlifamil@gmail.com

${ }^{2}$ Prof.Dr., Dokuz Eylül Üniversitesi, İktisadi ve İdari Bilimler Fakültesi, İşletme Bölümü, Yönetim Organizasyon Ana Bilim Dalı, gonul.budak@deu.edu.tr 


\section{GíRiş}

\section{F.MAJIDLİ - G.BUDAK}

Günümüzde küresel ekonominin genişlemesi, uluslararası göç hareketlerinin giderek daha da artması, farklılıkların yönetimi konusunun büyük önem taşımasına neden olmaktadır. Thomas R. R. (2011, s. 1-6)'ya göre üç farklı aşamadan oluşan farkl11ıkların yönetimi süreci 1980'li ylllardan itibaren örgüt içerisinde elverişli çevre yaratarak personelin maksimum potansiyeliyle çalışılmasına olanak sağlamayı amaçlayan işletme içi uygulamalara dönüşmüştür. R. Roosevelt Thomas (1991), Taylor Cox (1991, 1994, 2001) Gary Powell (1993), Gilbert vd. (1999), Robert Golembiewski (1995), Mor Barak (2000) ve diğer araştırmacılar tarafindan geliştirilen farklılıkların yönetimi modelleri işletmelere bu kapsamda uygulayacakları temel stratejiler anlamında 1şık tutmuştur. İsmet Barutçugil (2011), Olca Sürgevil Dalkılıç (2010) Türkçe literatürde farkl1lıkların yönetimi konusu ile ilgili önemli çalışmalara imza atmış, bu konuyla ilgili farkındalığın artması yönünde katkıda bulunmuşlar.

Farkl1lıkların yönetimi konusu, coğrafi konumundan dolayı farklı dini inançlara, etnik kökene, vb. özelliklere sahip bireyleri kendi bünyesinde bulunduran Türkiye açısından da önemli bir oluşum haline gelmektedir. T.C. İçişleri Başkanlığı Göç İdaresi Genel Müdürlüğü’nün (goc.gov.tr, 2017) istatistiklerine göre 16.11.2017 tarihi itibariyle 3.320.814 sayıda Suriyeli mülteciye kapısını açan ve aynı zamanda 09.11.2017 tarihi itibariyle 586.596 yabancı uyruklunun kayıtlı yaşadığı Türkiyenin geleceği açısından farklılıkların yönetimi konusunun dikkatli şekilde incelenerek; hem örgütler tarafından hem de hükumet düzeyinde uygun stratejilerin uygulanmasında fayda vardır. 
Çünkü farklılıklar konusu iyi yönetildiği takdirde örgütleri ve toplumları yaratıcılık, örgüt kültürü, problem çözme, maliyetlerin azalması ve gelirlerin artması gibi olumlu yönde etkilemektedir. Lakin farklılıklar iyi yönetilmediği takdirde anlaşmazlıklara ve çatışmalara yol açabilir ki, örgütler açısından bu çatışmaların yıkıcı sonuçlarından biri de mobbingdir. Baruçugil (2011, s. 214215) ve Gilbert vd. (1999, s. 64) de iyi yönetilmeyen farkl1lıklar yönetiminin bireylerin psikolojik, zihinsel durumlarına olumsuz etkide bulunduğunu, bu bireylerin psikolojik şiddete maruz kalma riskinin daha fazla olduğunu belirtmişler. Zapf (1999, s. 76), Fox ve Stallworth (2005, s. 452-453) Zukauskas ve Vveimhardt (2009, s. 4), Peguero \& Williams (2013, s. 548), Gökçe (2008), Ertürk (2013, s. 159) ve diğer bu gibi araştırmacılar da farklı ırk, kültür, etnik köken, dinsel, politik düşünceler, cinsel eğilim vb. özelliklerin mobbinge maruz kalma anlamında büyük risk taşıdığını çalışmaları sonucu elde ettikleri bulgulara dayanarak vurgulamaktadırlar.

Makalede, bu bulgulardan yola çıkarak, işletmeler içerisinde mobbingi engelleme kapsamında farklılıkların yönetiminin önemli bir olgu olduğunun altı çizilerek mobbingle mücadele adına farklılıkların yönetimi stratejileri geliştirilmiştir.

\section{FARKLILIKLARIN YÖNETIMI KAVRAMI}

1991 yılında yayınlanan "Managing Workforce 2000"de değişen örgütler için gerekli olan ve giderek daha da gelişmesi gerektiği düşünülen beş önemli yönetimsel yetenekten biri de farkl11lı̆g değer vermek, farklılıkları yönetmektir. Literatürde "farklılığa değer vermek" kavramını ilk defa kullanan "Copeland Griggs Productions" kavramı şu şekilde açıklamaktadır (Copeland Griggs Productions'dan akt. Jamieson \& O'Mara, 1991, s. 166-167): "Farkl1l1klara 


\section{F.MAJIDLI - G.BUDAK}

değer vermek anlayışı bireylerin farklı olduğunun, farklılıklara değer verilirse ve bu süreç iyi yönetilirse farklılıkların avantaj sağlayacağının ve farklılıkları hoş görmekle yetinmeyerek, aynı zamanda onları desteklemek, cesaretlendirmek ve farklılık kültürünü yerleştirmek gerektiğinin bilinmesi ve takdir edilmesidir.”

Farklılıkların yönetimi kapsamında belirtilen farklılık kavramı, genel anlamda, şirket içerisinde çeşitli sosyo-kültürel birikimlere sahip çalışanların bir arada bulunduğunu belirtmektedir (Henry \& Evans, 2007, s. 73). Cox (2001, akt. Kamal\&Ferdousi, 2009, s. 157) farklılığı bugünkü istihdam ve pazarlama ortamında birlikte var olan insanlar arasındaki sosyal ve kültürel kimliklerin varyasyonu gibi tanımlamaktadır. Thomas ve Ely (1998, akt. Kamal\&Ferdousi, 2009, s. 157) ise; farklılı̆̆ın; farklı kimlik guruplarına sahip üyelerin işyerine getirdikleri çeşitli deneyimler ve yaklaşımlar gibi anlaşılabilineceği fikrini savunmaktadırlar. Hubbard (2004, s. 27)'a göre farklılık; örgüt hedefleri doğrultusunda kabul edilmiş benzerlik ve farklılıklar tarafindan belirlenen kolektif karışımdır.

Farklılıkların yönetimi konusunu ilk defa ele alarak değerlendiren araştırmacılardan biri olan Thomas (2011, s. 1)'a göre farkll1ıkların yönetimi, hem farkl1liklar ve benzerliklerle ilgili, hem de bu iki kavramın ortasında yer alan gerginlikler ve karışıklıklarla başa çıkmak için kaliteli karar verme yeteneğidir. Burada kaliteli karar, örgütün misyonu, vizyonu ve stratejisine eşdeğer olan bir eylem olarak tanımlanmaktadır.

Rosado (2006, s. 4)'ya göre ise; farkl1l1k yönetimi örgütlerde, toplumlarda örgütsel yararlar için farklı diye nitelendirilebilecek insanların çeşitli yeteneklerini ve becerilerini ortaya çıkaran, ahlak açısından hiç bir sakıncası 
olmayan, kapsayıcı bir çevre oluşturarak insanlara "kabul etmemeyi reddetmek" olanağını sunan, farklılığa değer veren ve örgütte farklılığı artıran devamlı bir süreçtir.

Farklılıklar yönetimi ile ilgili çeşitli tanımlardan yola çıkarak, bu kavramın farklılıkları kabul etmek, farklı özelliklere sahip bireylere değer vermek ve aynı zamanda örgütler için rekabet üstünlüğü sağlayan ve örgütlere birçok avantajlar sağlayan bir olgu olduğu söylenebilir.

\section{FARKLILIKLARIN ETKİLERI}

Toplum içinde insanların sahip oldukları farklı özellikler, hem bireyleri, hem örgütleri, hem de toplumları çeşitli açılardan etkilemekle beraber günümüzde bu farklılık unsurları uluslararası çerçevede de önemli ölçüde kendi etkisini göstermektedir. Yapacağımız yazın taramasında biz sadece farklılıkların bireysel ve örgütsel etkilerini ele alıp değerlendireceğiz.

\subsection{Farklılıkların Bireysel Etkileri}

Farklı özelliklere sahip bireyler etraflarındaki insanların onlara karşı olumlu veya olumsuz tutumlarından, toplumda ayrımcılığın olup olmamasından, önyargılardan ve yüzyıllarca toplumların hafızasına kazınmış stereotiplerden büyük ölçüde etkilenmektedirler. İnsan hakları ile ilgili çok sayıda çalışmanın yürütüldüğü, özellikle Batı dünyasında, insana verilen değerin artmasıyla birlikte günümüzde farklılık konusu oldukça hassas hale gelmiştir.

Ne yazık ki, farklılıkların yönetimi süreci henüz tam olarak başarılı bir şekilde yönetilememektedir, şöyle ki; 1970'lerin başlarından itibaren farklılıklarla ilgili literatürde sık sık görülmeye başlayan, insanlar arasında adaleti sağlamak, azınlıklara değer vermek adına olumlu bir olgu olarak ortaya 


\section{F.MAJIDLI - G.BUDAK}

çıkan Olumlu Eylem ve Eşit İstihdam Fırsatı gibi farklı1ıklarla ilgili yönetim politikalarının, toplumda dominant çoğunluğa sahip bireyler tarafından kendilerine karşı adaletsiz bir anlayış olarak algıladıklarını ifade eden "Tersine Ayrımcılık (Reverse Discrimination)" durumu, doğru şekilde uygulanmayan farkl11ıkların yönetimi stratejileri, beyazlar ve erkekleri olumsuz yönde etkilemektedir (en.wikipedia.org, 2016). Günümüzde yapılan birçok araştırmada da toplumlarda veya örgütlerde çoğunluğu teşkil eden bireylerin, haksızlığa uğradıklarını iddia ettikleri görülmektedir (Dover vd., 2016).

Gilbert vd. (1999, s. 64), pozitif ayrımcılı̆̆ın azınlıklar üzerinde de olumsuz etkide bulunduğunu belirtmektedirler. Şöyle ki; araştırmacılar yapılan bazı araştırmalardan yola çıkarak pozitif ayrımcılık koşulları altında çalışma hayatına kabul edilen kadınların kendi cinsiyetlerinin işe alımlarda sorumlu ya da etkin olmadığını bilen kadınlara göre daha çok stres yaşadıkları, iş doyumlarının daha az olduğu sonucuna varmışlardır.

Yıllarca ayrımcılığa maruz kalmış farklı özelliklere sahip insanlarda bile önyarg1 ve stereotip ortaya çıkmıştır. $\mathrm{Bu}$ insanlar, toplum içinde kendilerini psikolojik açıdan rahat hissetmemekte ve kendilerine karşı gösterilen en ufak haksızlıkları ayrımcılık olarak adlandırmaktadırlar. Bunun da temel nedeni, azınlık gruba mensup insanların kendilerine olan güvenlerinin tam olarak oturmamış olması ve buna bağlı olarak da algılarının daha kolay bozulabilmesinden kaynaklanabilmektedir.

Yukarıda da belirtildiği gibi farkl1lık süreci iyi yönetilmediği takdirde, bireyleri-özellikle psikolojik açıdan olumsuz yönde etkilenebilmektedir. Ama bu süreç iyi yönetilirse, Barutçugil'in de söylediği gibi bireylere rahatlık ve güvenlik duygusu, yaşama sevinci, çalışma isteği gibi olumlu psikolojik 
özellikler aşılanmış olup, hem çalışma ortamlarında, hem de toplumda fiziksel ve zihinsel sağlığı olumlu yönde etkileyeceğinden, yanlış anlamalardan doğan çatışmalar ve duygusal sorunlar önlenebilecektir (Barutçugil, 2011, s. 214-215).

\subsection{Farklılıkların Örgütsel Etkileri}

Farklılıkların bireysel etkilerinden söz ederken görüldüğü gibi farklılıklar başarılı bir şekilde yönetilmediği takdirde bireylerin psikolojik açıdan kendilerini rahatsız hissetmesine neden olmaktadır. Bu durum da örgütlerde çalışanlar arasında çatışmaların ortaya çıkmasına yol açabilir ki, Budak (2013, s. 484); bu durumun asil nedeninin insanların kendilerine benzeyenlerin yanında daha rahat ve daha güvende, kendilerinden farklı olan insanların yanındaysa huzursuz hissetmelerinden kaynaklandığını belirtmektedir.

Gilbert vd., başarılı şekilde yürütülen farklılıkların yönetimi çalışmaları sonucunda, işletmelerin elde edebileceği faydaları aşağıdaki gibi açıklamaktadırlar (Gilbert vd., 1999, s. 65):

1. Maliyetlerde azalma - işgücü devri ve işe gelmeme oranında azalmalar,

2. Kaynak sağlama - rakiplerin işgücü havuzu daralırken ve değişirken en iyi personel adaylarını etkilemek,

3. Pazarlama çabalarına içsel ve kültürel duyarlılık getirmek,

4. Yaratıcılık - yenilik ve yaratıcılık girişim düzeyini artırmak,

5. Problem çözme - daha geniş bakış açılarına sahip olma ve daha başarılı eleştirel analizler yapmak,

6. Sistem esnekliği - çevresel değişikliklere hızlı ve daha az maliyetle cevap verebilmek. 


\begin{abstract}
F.MAJIDLİ - G.BUDAK
Memduhoğlu birçok araştırmadan yola çıkarak farklılık yönetiminin yukarıda söylenilen avantajların yanı sıra iş doyumu, müşteri memnuniyeti, verimlilik, halkla ilişkiler, işletme imajı, takım çalışmalarında sinerji açısından örgütleri olumlu yönde etkilediğini söylemektedir. Bunun yanında yazar çalışanların, farklı özelliklerinin işletmeleri olumsuz yönde etkilediğini de belirtmiş, bu olumsuz etkilerin özellikle çalışanların örgütlere bağlılık, örgüt içi sağlıklı iletişim, çatışma, ayrımcılığg meşrulaştırma konularında kendini gösterdiğinin altını çizmiştir (Memduhoğlu, 2007, s. 64-73).
\end{abstract}

Görüldüğü gibi örgütlerde farklılıkların iyi yönetilmesi, birçok işletme içi alanda pozitif katkıda bulunarak işletmelerin daha da gelişmesine, başarılı bir şekilde faaliyetlerini yürütmesine neden olmaktadır.

\title{
4. FARKLILIKLARIN YÖNETIMI MODELLERİ
}

Farklılıkların yönetimi ile ilgili modeller konunun bireyler, örgütler ve toplumlar tarafindan nasıl algılandığını ve yorumlandığını anlamayı kolaylaştırmaktadır (Barutçugil, 2011, s. 206). Farklılıkların yönetimi modelleri incelendiğinde literatürde bu modellerin üç ana başlık altında sınıflandırıldığı görülmektedir (Sürgevil, 2010, s. 131-161; Eğinli, 2009, s. 214-251): İlk Modeller; Ara Modeller ve Süreç Modelleri. Bu sözü edilen modeller aşağıda ele alınacaktır:

\section{1. İlk Modeller}

Farklılıklarla ilgili yapılmış İlk Modeller'de örgütleri farklılıklara karşı olan tepkileri, yaklaşımları ve bu farklılıkları nasıl algıladıkları ile ilgili sınıflandırmalar yapılmıştır. Bu modellerin her birinde örgütlerin farklılıklara yaklaşımı üç farklı kategoride değerlendirilmiştir. Agars ve Kottke bu modeller 
kapsamında yer alan yaklaşımların en kötüden en iyiye doğru ilerlediğini ve en son aşamada örgütlerin farklılıklara karşı arzulanan, ideal kabul edilebilecek gerekli tutumları, yaklaşımların neler olduğu ile ilgili incelemelere yer verildiğini belirtmektedir. Özetle, ilk modeller örgütlerin farklılık yönetimi kapsamında nasıl bir yol izlemesi gerektiğine, bir aşamadan diğerine geçtikleri zaman yapmaları gereken şeylerin neler olduğuna dikkat çekmektedir. Tablo 1 'de İlk modellerin, teorisyenlerin temel ilkelerinin, odak noktalarının neler olduğu görülmektedir (akt. Eğinli, 2009, s. 233; Sürgevil, 2010, s. 132).

Tablo 1. Farklılık Yönetimi ile İlgili İlk Modeller

\begin{tabular}{|l|l|l|}
\hline \multicolumn{1}{|c|}{ Model Adı } & Teorisyen Adı & \multicolumn{1}{c|}{ Temel İlkeleri/ Odak Noktaları } \\
\hline $\begin{array}{l}\text { R. Roosevelt Thomas } \\
\text { Modeli (1991) }\end{array}$ & $\begin{array}{l}\text { R.Roosevelt } \\
\text { Thomas }\end{array}$ & $\begin{array}{l}\text { Olumlu eylem, Farklılıklara değer verme, } \\
\text { Farklılıkları yönetme }\end{array}$ \\
\hline Taylor Cox Modeli (1991) & Taylor Cox & $\begin{array}{l}\text { Tek kültürlü örgüt, Çoğulcu örgüt, Çok } \\
\text { kültürlü örgüt }\end{array}$ \\
\hline Gary Powell Modeli (1993) & Gary Powell & Proaktif örgüt, Reaktif örgüt, Nötr örgüt \\
\hline $\begin{array}{l}\text { Robert Golembiewski } \\
\text { Modeli (1995) }\end{array}$ & $\begin{array}{l}\text { Robert } \\
\text { Golembiewski }\end{array}$ & $\begin{array}{l}\text { Baskı altında farklılık, eşit firsatlar, artan } \\
\text { olumlu eylem, farklılıklara değer verme, } \\
\text { farklılıkları yönetme }\end{array}$ \\
\hline
\end{tabular}

Kaynak: Eğinli, 2009: 232.

\subsection{Ara Modeller}

Ara Modeller olarak gruplanmış olanlar örgütlerin farklılık kavramına dair tepkileri, yaklaşımlarının neler olduğundan daha çok öğrenme odaklı bir yaklaşımının benimsenmesiyle ilk modellerden ayrılırlar. Agars ve Kottke’nin de belirttiği gibi "Öğrenen örgüt” kavramı, farklılıkların yönetimi kavramı ile anlamlı şekilde bütünleşmektedir (akt. Sürgevil, 2010, s. 137). Ara Modeller’de farklılıklarla ilgili ideal yaklaşımları benimsemiş olan örgütlerin, farklılıkların yönetimi sürecinde hangi yolları izlemeleri gerektiği açıklanmaktadır. Tablo 


\section{F.MAJIDLI - G.BUDAK}

2'de Ara Modeller'in hangileri olduğu, teorisyenlerinin kimler olduğu ve temel ilkelerinin, odak noktalarının neler olduğu verilmektedir.

Tablo 2. Farklılık Yönetimi ile İlgili Ara Modeller

\begin{tabular}{|c|c|c|}
\hline Model Adı & Teorisyen Adı & $\begin{array}{c}\text { Temel İlkeleri/ Odak } \\
\text { Noktaları }\end{array}$ \\
\hline $\begin{array}{l}\text { Thomas ve Ely Modeli } \\
\text { (1996) }\end{array}$ & $\begin{array}{l}\text { David A. Thomas ve } \\
\text { Robin J.Ely }\end{array}$ & $\begin{array}{l}\text { Fark gözetmeme ve tarafsızlık } \\
\text { yaklaşımı, giriş ve yasallık } \\
\text { yaklaşımı, öğrenme ve etkililik } \\
\text { yaklaşımı }\end{array}$ \\
\hline Taylor Cox Modeli (2001) & Taylor Cox & $\begin{array}{l}\text { Liderlik, Ölçme ve Araştırma, } \\
\text { Eğitim, Yönetim sisteminin } \\
\text { düzenlenmesi, Süreklilik }\end{array}$ \\
\hline $\begin{array}{l}\text { Richard Allen ve Kendyl } \\
\text { Montgomery } \\
\text { Yaratma Modeli } \\
\text { (2000) }\end{array}$ & $\begin{array}{l}\text { Richard Allen ve Kendyl } \\
\text { Montgomery }\end{array}$ & $\begin{array}{l}\text { Çözme, değişim, yeniden } \\
\text { tasarlama, rekabetçi üstünlük }\end{array}$ \\
\hline $\begin{array}{l}\text { Tam Bütünleşme Modeli } \\
\text { ( 2002) }\end{array}$ & $\begin{array}{l}\text { Mark D. Agars, Janet L. } \\
\text { Kottke }\end{array}$ & $\begin{array}{l}\text { Sorun tanımlama, uygulama, } \\
\text { sürdürülebilirlik }\end{array}$ \\
\hline $\begin{array}{l}\text { Mor Barak Kapsayıc1 } \\
\text { Farklılık Yönetimi Modeli } \\
(2000)\end{array}$ & Mor Barak & $\begin{array}{l}\text { Değer ve uygulama tabanlı } \\
\text { model, kapsama -dişlama }\end{array}$ \\
\hline
\end{tabular}

Kaynak: Eğinli, 2009: 232.

\subsection{Süreç Modelleri}

Süreç modellerinin şimdiye kadar sıralanan Modellerden farkı özellikle örgüt fonksiyonlarına ve farklılıklara ilişkin boyutların örgütün öğeleri ile etkileşim sonucundaki örgütsel çıktılarına nasıl dönüştüğüne odaklanılmasıdır. Cox'un Farklılık Yönetimi Etkileşimsel Modeli, Gilbert vd.'lerinin Bütünleştirilmiş Etkili Farklılık Yönetimi Modeli, Dreachslin vd.'lerinin Irksal ve Etnik Farklılıkların Yönetimi Modeli ve Pitts'in Kapsamlı Farklılık Yönetimi Modeli süreç modelleri kapsamına girmektedir.

Burada özellikle Gilbert vd.'leri tarafindan geliştirilen Bütünleştirilmiş Etkili Farklılık Yönetimi Modeli (Şekil 1.) ele alınarak değerlendirilmektedir. 
Model'de farklılık yönetiminin örgütler açısından iki yönde - adalet ve elde edilen kar - katkı sağladığına inanan CEO'ların farklı1ık yönetimi sürecinde çok ciddi sorumluluklar üstlendikleri belirtilmektedir. Yazarlar CEO'ların ateşleyici ve devamlı çabalarının farklılığa karşı olumlu tutumların oluşturulması, azınlık ve çoğunluk gruplar açısından olumlu sonuçlar elde edilmesi için insan kaynakları fonksiyonlarının dönüşümüne neden olduğunu vurgulamaktadırlar.

Model'de insan kaynakları fonksiyonlarının dönüşümünün çalışanların örgütsel bağl1lığının artması, nitelikli azınlıkların işe alınması ve örgütte tutulması gibi örgütsel sonuçlar ve psikolojik uyumsuzluk, bütünleşme, cam tavan etkileri gibi bireysel sonuçlar açısından önemli değişikliklere neden olduğu belirtilmektedir. Model'in odak noktası olan CEO'lar tarafından oluşturulan ve yine onların faaliyetleri sayesinde çalışanlar tarafından benimsenen çok kültürlülük anlayışı, farklılıkları kabul etme ve değer verme gibi farklılıkla ilgili tutumların da yine örgütsel sonuçlar üzerinde etkili olduğu vurgulanmaktadır.

Gilbert vd., son olarak etkin şekilde yönetilen farkl1lık yönetiminin pazar payının, toplam karın ve hisse fiyatlarının artması gibi örgütsel çıktılar ve toplumsal açıdan da pozitif örgüt imajının oluşturulması kapsamında en önemli süreçlerden biri olduğunu söylemektedirler (Gilbert vd., 1999, s. 66-70). 


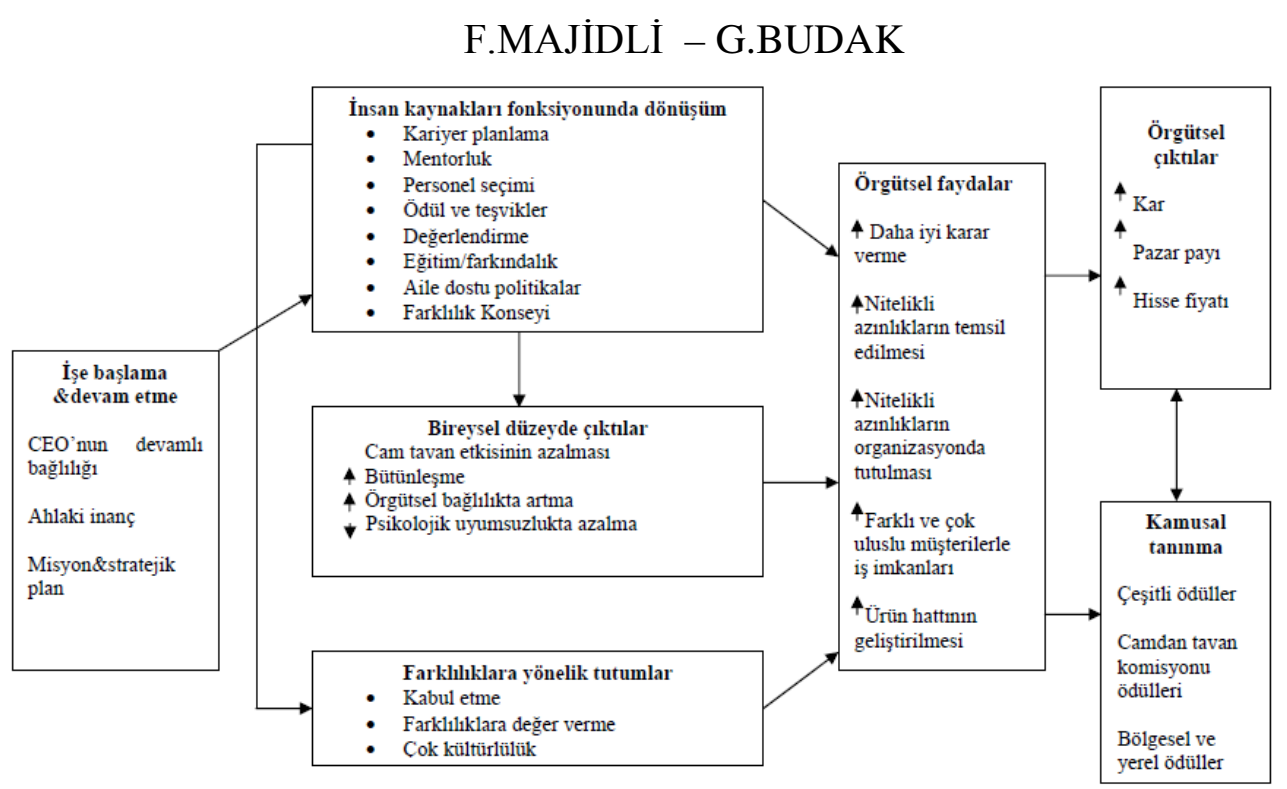

Şekil 1. Bütünleştirilmiş Etkili Farklılık Yönetimi Modeli

Kaynak: Gilbert vd., 1999: 67.

\section{MOBBINGIN TANIMI VE DAVRANIŞ TÜRLERİ}

Son bir kaç y1lda literatürde sıkça rastlanmaya başlayan "Mobbing" kavramı insanların beraber yaşadıkları, her hangi bir faaliyette bulundukları bütün topluluklarda kendini gösteren en önemli sorunlardan biridir.

İşyerlerinde mobbing sorunun varlığıdan ilk söz eden bilim insanı alman endüstri psikoloğu Leymann’a göre; “zorbalık”, "psikolojik terör”, "birine karş1 çeteleşmek" gibi eşanlamları taşıyan mobbing "Bir veya birkaç kişi tarafından, diğer bir kişiye yönelik olarak, düşmanca ve ahlak dışı yöntemlerle sistematik bir biçimde uygulanan psikolojik bir terördür” (akt. Çobanoğlu, 2005, s. 28). Rohland'a (2015) göre ise; her hangi bir bireyin topluluk tarafindan maruz kaldığı zorbalık olarak nitelendirilen mobbing, bireylere fiziksel saldırıdan daha çok psikolojik saldırıları içermektedir ve bireyler bu tip saldırılara uzun bir zaman kesiminde maruz kalmaktadırlar. 
Mobbing vakaları incelendiğinde mobbing kurbanlarının çeşitli şekillerde mobbing davranışlarına maruz kaldıkları görülmektedir. Dr. Heinz Leymann, Avrupa ülkelerinde yaptığı araştırmalar sonucunda 45 farklı mobbing davranışının varlığından söz etmekte ve bu davranışları 5 grup altında ayrı ayrı ele alarak değerlendirmektedir ki, bu davranışlar aşağıdaki gibidir (Leymann, 1996, s. 170; Davenport vd., 2003, s. 18-19).

\section{a. Kendini Göstermeyi ve İletişim Oluşumunu Etkilemek}

1. Üstünüz kendinizi gösterme olanaklarını kısıtlar.

2. Sözünüz sürekli kesilir.

3. Meslektaşlarının veya birlikte çalıştığınız kişiler kendinizi gösterme olanaklarınızı kısıtlar.

4. Yüzünüze bağırılır ve yüksek sesle azarlanırsınız.

5. Yaptığınız iş sürekli eleştirilir.

6. Özel yaşamınız sürekli eleştirilir.

7. Telefonla rahatsiz edilirsiniz.

8. Sözlü tehditler alırsınız.

9. Yazılı tehditler gönderilir.

10. Jestler ve bakışlarla ilişki reddedilir.

11. İmalar yoluyla ilişki reddedilir.

\section{b. Sosyal İlişkilere Saldırılar}

1. Çevrenizdeki insanlar sizinle konuşmazlar.

2. Kimseyle konuşamazsınız, başkalarına ulaşmanız engellenir.

3. Size diğerlerinden ayrılmış bir işyeri verilir.

4. Meslektaşlarınızın sizinle konuşması yasaklanır.

5. Sanki orada değilmişsiniz gibi davranılır. 


\section{c. İtibarınıza Saldırılar}

\section{F.MAJIDLI - G.BUDAK}

1. İnsanlar arkanızdan kötü konuşur.

2. Asılsız söylentiler ortalıkta dolaşır.

3. Gülünç durumlara düşürülürsünüz.

4. Akıl hastasıymışsınız gibi davranılır.

5. Psikolojik değerlendirme / inceleme geçirmeniz için size baskı yapilır.

6. Bir özrünüzle alay edilir.

7. Sizi gülünç düşürmek için yürüyüşünüz, jestleriniz veya sesiniz taklit edilir.

8. Dini veya siyasi görüşünüzle alay edilir.

9. Özel yaşamınızla alay edilir.

10. Milliyetinizle alay edilir.

11. Özgüveninizi olumsuz etkileyen bir iş yapmaya zorlanırsınız.

12. Çabalarınız yanlış ve küçültücü şekilde yargılanır.

13. Kararlarınız sürekli sorgulanır.

14. Alçaltıcı isimlerle anılırsınız.

15. Cinsel imalar yapılır.

\section{d. Kişinin Yaşam Kalitesi ve Mesleki Durumuna Saldırılar}

1. Sizin için hiçbir özel görev yoktur.

2. Size verilen işler geri alınır, kendinize yeni iş bile yaratamazsınız.

3. Sürdürmeniz için anlamsız işler verilir.

4. Sahip olduğunuzdan daha az yetenek gerektiren işler size verilir.

5. İşiniz sürekli değiştirilir.

6. Özgüveninizi etkileyecek işler verilir. 
7. İtibarınızı düşürecek şekilde, niteliklerinizin dışındaki işler size verilir.

8. Size mali yük getirecek genel zararlara sebep olunur.

9. Eviniz ya da işyerinize zarar verilir.

\section{e. Kişinin Sağılığına Doğrudan Saldırılar}

1. $\quad$ Fiziksel olarak ağır işler yapmaya zorlanırsınız.

2. Fiziksel şiddet tehditleri yapılır.

3. Gözünüzü korkutmak için hafif şiddet uygulanır.

4. Fiziksel zarar.

5. Doğrudan cinsel taciz.

Yukarıda sıralanan bu davranışların en az birkaçı ile belki de her bir çalışan iş yaşamında karşılaşmaktadırlar. Ama bu davranışların mobbing olarak algılanabilmesi için gereken bazı parametreler vardır ki, Herald Ege bu parametreleri aşağıdaki şekilde açıklamaktadır (akt. Tutar, 2015, s. 116-117):

$>$ İşyerinde olmalı - Mobbing işyerinde olmak veya işyerine bağlı bir faaliyet kapsamında olmak durumundadır.

$>$ Süre - Mobbing olayı en azı 6 aylık bir süreci kapsamalıdır. Yalnız bu durumda sistematik bir mobbing davranışından söz edilebilinir. Altı aydan az bir süreyi kapsayan mobbing akut, altı aydan daha fazla süreyi kapsayan mobbing ise; kronik mobbing sayılmaktadır.

> Frekans - Çatışmalar ayda bir kaç kez kendini göstermelidir.

$>$ Eylem - Mobbing tanımına uygun yukarıda açıklanan davranışların varlığı gerekmektedir. 


\section{F.MAJIDLI - G.BUDAK}

$>$ Eşitsizlik - Burada örgütsel anlamda bir hiyerarşi eşitsizliğinden daha çok güç eşitsizliğinden, cinsiyet, statü ve bu gibi diğer eşitsizliklerin varlığından söz edilmektedir.

\section{MOBBINAG NEDENLERİ}

Yöneticiler için şirkette mobbingi önlemek adına gerekli olan bilgilerden biri de mobbingin nereden kaynaklandığını, onun nedenlerini öğrenmek ve bu nedenleri mümkün olduğu kadar azaltmaya çalışmaktır. Mobbingin nedenlerinin net olarak neler olduğuna dair çeşitli fikir ayrılıkları vardır. Davenport vd.'lerinin (2003, s. 37) söylediği gibi “mobbing, zorba bir patron gibi tek bir nedene bağlanamayacak kadar karmaşıktır”.

Mobbing nedenleri ile ilgili çeşitli çalışmaları incelendikten sonra işyerlerinde mobbinge yol açan bütün faktörleri; 1) Saldırgandan Kaynaklanan, 2) Mobbing Mağdurundan Kaynaklanan, 3) Örgütsel ve 4) Toplumsal Nedenler olarak dört ana başlık altında sınıflandırabilmek mümkündür.

\subsection{Saldırgandan Kaynaklanan Nedenler}

Zapf'ın (1999, s. 76) mobbing nedenleri ile ilgili yaptı̆̆ı araştırmada mağdurlar, mobbing sürecinin çoğunlukla saldırgandan kaynaklanan nedenlerle ortaya çıktığını savunmaktadırlar. Şöyle ki; mağdurların \% 66'sı saldırganların onların işten kovulmalarını istediklerini, \% 62’si ise; düşmanın - saldırganın diğer çalışanları kendilerine karşı olumsuz yönde etkilediklerini söylemektedirler. Bir diğer çalışmadaysa, 30 İrlandalı mobbing mağdurunun hepsinin saldırganın zor kişilik yapısının mobbinge yol açtığı vurgulanmaktadır (Einarsen vd., 2010, s. 180). 
Bazı araştırmalarda ise; mağdurlarla yapılan konuşmalar sırasında kıskançlığın en dikkate değer mobbing nedeni olduğu bilgisi elde edilmiştir. Vartia'nın yaptığı araştırmada mobbing olaylarının \% 68'inde kıskançlık duygusunun tetikleyici unsur olduğu ortaya çıkmaktadır (Einarsen vd., 2010, s. 182). Norveçte, 278 kişi arasında yapılmış araştırmada da kıskançlığın en büyük ortak neden olduğu sonucuna varılmıştır (Einarsen, 1999, s. 20).

\subsection{Mobbing Mağdurundan Kaynaklanan Nedenler}

Literatürde mobbing mağdurlarının sahip oldukları kişilik özellikleri ile ilgili çeşitli görüşler mevcuttur. Bazı bilim insanları kurbanların dürüst, güvenilir, işbirlikçi, özgüveni yüksek, girişken, kendilerini başkalarına beğendirme çabası olmayan, aşırı derecede vicdanlı, örgüt bağlılı̆̆ı yüksek, onurlu, işleriyle özdeşleşme ve bu gibi birçok olumlu özelliklere sahip olduklarını vurgulamaktadırlar (Özler \& Mercan, 2009, s. 22). Çobanoğlu (2005, s. 52); kurbanların eğitim, dış görünüş, entellektüel birikim açısından parlak elemanlar olduğunu belirtmektedir. Zapf vd., Davenport vd. de mobbing mağdurlarını çalışkan, başarılı, güvenilir ve yukarıda sıralanan diğer pozitif özelliklere sahip kişiler olarak tanımlamaktadır (akt., Ançel, 2012, s. 94-95).

Bazı bilim insanları ise; kurbanlarda gözlemlenen bir takım psikolojik ve diğer sağlık sorunlarının mobbinge neden olduğunu belirtmektedirler. Örneğin, Einarsen ve Matthiesen (2001, s. 479), mobbing mağdurlarının MMPI-2 (Minnesota Çokyönlü Kişilik Envanteri - kapsamlı bir kişilik testi) kişilik profillerini belirlemek için yaptığı çalışmada ağır bir şekilde mobbinge maruz kalan bireylerin depresif, endişeli, şüpheci, özgüvenleri düşük ve karmaşık kararlar kaşısında zorlanan bireyler olduğuna ilişkin verilerin bulunduğunu belirtmektedir. Einarsen, kişilerin olumsuz düşüncelerinin ve duygularının 


\section{F.MAJIDLI - G.BUDAK}

yüksek olmasının karamsarlığa neden olacağını ve bunun sonucunda da bu kişilerin kendilerinin ve çevresindekilerin negatif yönlerine odaklanarak potansiyel tehditlere daha çok meyilli olduklarını ve bundan dolayı diğerlerine göre mobbinge maruz kalma risklerinin daha yüksek olduğunu savunmaktadır (akt. Ertürk, 2013, s. 158).

Biz ise; burada daha çok farkl1lıklar konusuna odaklanarak mobbingin nedenlerini mağdurların farklı bireysel özellikleri açısından değerlendirmeye çalışacağız.

\subsubsection{Farklı Bireysel Özellikler}

Yapılan bazı araştırmalarda mobbing mağdurları, sahip oldukları farklı özelliklerden dolayı mobbinge maruz kaldıklarını iddia etmektedirler. Gökçe (2008) ve Ertürk'e (2011) göre, bir kişinin farklı kültüre veya etnik kökene sahip olması, onun mobbinge maruz kalmasina neden olabilir (akt. Ertürk, 2013, s. 159). Leymann (1993) da farklı rrksal, sosyal ve etnik gruba üye insanların mobbinge maruz kalma ihtimalinin yüksek olacağından söz etmektedir (akt. Özler \& Mercan, 2009, s. 28). Zapf'ın (1999, s. 76) mobbing nedenleri ile ilgili araştırmasında kurbanların \% 21'i farklı olduklarından, \% 8'i dinsel, politik düşüncelerinden, \% 8'i cinsiyet konusundan, \% 6's1 sahip olduğu engellilikten, \% 5'i dış görünüşünden, \%2'si milliyetinden dolayı mobbinge maruz kaldıklarını belirtmişlerdir. Lee, mobbing mağdurlarıyla ilgili örnek olay çalışmalarında cinsiyet rollerinin mobbinge maruz kalma anlamında büyük bir risk taşıdığını vurgulamaktadır (akt. Hoel vd., 2002, s. 310).

Zukauskas ve Vveinhardt (2009, s. 4), mobbingin işyerinde ayrımcıllğın başka bir biçimi olarak ortaya çıktığını vurgulamaktadır. Yazarlar yaş durumu, eğitim seviyesi, cinsiyet ve iş deneyimi ile mobbing arasındaki ilişkileri 
incelemiş ve yaşlı bireylerin, eğitim seviyesi daha fazla olan kişilerin, kadınların ve özellikle 4 yıldan 7 yıla kadar iş deneyimine sahip olan bireylerin daha fazla mobbinge maruz kaldıklarına dair bulgular elde etmişıler (Žukauskas \& Vveinhardt., 2009, s. 12-15).

Irksal farklılıklar da mobbinge yol açan bireysel özelliklerden biri olarak bilinmektedir. ABD'de okullarda mobbing ile ilgili araştırmalarda zamanı Afroamerikalıların, İspanyolların, Asyalıların kendilerine karşı önyargılardan rahatsız oldukları, onların sözlü tacizlere, aşağılayıcı davranışlara, sosyal dışlamalara maruz kaldıkları ile ilgili vakalara rastlanılmıştır (Peguero \& Williams, 2013, s. 548).

Fox ve Stallworth'un (2005, s. 452-453) 1rksal - etniksel özellikler ve mobbing arasındaki ilişkiyi belirlemek için 262 tam zamanlı çalışan arasında yapılan araştırma sonuçlarına göre; genel mobbing ve aynı zamanda ırksal etnik mobbing ile duygusal tepki arasında yüksek düzeyde bir bağlılığın olduğu sonucuna varılmıştır. Buradaki duygusal tepki, bireylerin sahip oldukları farklılığa göre oluşan duygusal tepki olarak tanımlanmaktadır. Yazarlar ayrıca mobbingi; genel mobbing ve 1rksal - etniksel mobbing diye ikiye ayırmaktadırlar ki, genel mobbinge her bir insan maruz kalabilirken, ikinci tür mobbing ise; farklılıklarla ilgili şakalar, hakaretler, sosyal dışlanmaları ve aşağılayıcı davranışları içermektedir ve kişinin sahip olduğu farklılıktan kaynaklanır.

\section{3. Örgütsel Nedenler}

Einarsen, mobbingin örgütsel nedenlerinden söz ederken Norveçte, 2200 kişi arasında yapılan anket sonucunda; yapıcı liderlik eksikliği, görevlerin kontrolü, özellikle yüksek düzeyde rol çatışmalarının çözümlenmesi, zaman 


\section{F.MAJIDLI - G.BUDAK}

yetersizliği, çelişkili talepler, işlerle ilgili beklentilerden doğan stres gibi özelliklerin mobbinge neden olabileceğini vurgulamaktadır. Finlandiya'da yapılmış bir diğer araştırmadaysa; zayıf bilgi akışı, otoriter yönetim tarzı, hedefler ve görevlerle ilgili müzakerelerin olmaması gibi özelliklerin de mobbinge yol açan unsurlardan olduğu bilgisi elde edilmiştir. Bazı araştırmalarda örgütsel değişim ve mobbing arasında ilişki olduğu kanısına varılmıştır (Einarsen S., 1999, s. 22).

Ayrıca günümüz iş dünyasında ulusal sınırların neredeyse aradan kalkmasıyla işletmeler faaliyetlerini sürdürebilmeleri ve pazarlarda tutunabilmeleri için birçok stratejik kararlar almalıdırlar ki, bunlardan biri de; işletmelerin yapısal değişikliğe gitmesi yani küçülmesi veya büyümesidir. Özellikle küçülme; iş ortamında mobbingin ortaya çıkmasına neden olabilmektedir. Başka bir değişim yapısı ise; kademe azaltma olarak bilinmektedir ki, bu kavram hiyerarşinin azalması olarak tanımlanabilir. Bu durumda da çalışanlar işlerini kaybedebilmektedirler ve hem küçülme, hem de kademe azaltma durumundaki bireyler işlerini kaybetmek korkusu ile diğer çalışma arkadaşına daha fazla mobbing uygulayabilirler (Özler \& Mercan, 2009, s. 104).

Mobbingi ortaya çıkaran diğer nedenlerden biri ise; olumsuz örgüt kültürü ve iklimidir. Mobbingin gözlemlendiği örgütlerde daha gergin ve rekabetçi örgütsel iklim egemen olmakta, böyle çatışmacı, stresli ve aynı zamanda yüksek performansa odaklanmış örgüt kültürünün mobbinge yol açtığ1 düşünülebilmektedir (Tutar, 2015, s. 147). Vartia, mobbing davranışlarının örgüt iklimindeki psikolojik nedenlerini incelediği çalışmasında mobbing ile örgüt iklimi arasında bir ilişkinin olduğunu ortaya koymuştur. Einarsen'in de 
elde ettiği bulgular, Vartia'nın bu görüşünü desteklemekte, düşmanlık içeren örgüt ikliminin potansiyel mobbing kaynağı olduğunu belirtmektedir (Ertürk, 2013, s. 154).

Örgütteki yönetim tarzı ve liderlik; ister başarı olsun, isterse de başarısız olsun belki de her ikisinin ana nedenlerinden en başta gelenidir. Leymann, birçok durumlarda kötü yönetim tarzının ve liderlik sorunlarının mobbinge yol açtığını belirtmektedir ki, Einarsen, Vartia, Zapf ve Osterwalder'ın araştırmaları da bu görüşü desteklemektedir (akt. Zapf, 1999, s. 82). Bazı durumlarda ise; kurbanlar tarafından liderlerin ve yöneticilerin saldirgan olarak değerlendirildiği görülmektedir (Hoel vd., 2010, s. 454).

İnsan Kaynakları Yönetimi uygulamalarında ortaya çıkan eksiklikler de mobbinge yol açabilmektedir. Mobbing kapsamında İKY departmanı tarafından ortaya çıkan ilk eksiklik, işe alımlarda görülebilmektedir. Şöyle ki, işe alınan bireyin psikolojik kişilik durumunun doğru şekilde belirlenmemesi ve kişilik bozukluğuna sahip birinin işe alınması durumunda bu bireyin kişilik özelliği gelecekte bir mobbing olayının başlanmasına neden olabilir. Uyum eğitimi, çatışma yönetimine yönelik eğitimlerde karşılaşılan eksiklikler sonucunda mobbingin ilk aşamasından çıkarak, diğer aşamalara ayak basmasını tetikleyebilir.

İş dizaynı, güvenilir iş ortamı gibi çalışanlar açısından önem arz eden faktörlerin varoluşu da İKY sorumluluğundadır. Çalışanlara iyi bir iş ortamı hazırlanması için örgütte stresin ortadan kaldırılmasına önem vermek gerekmektedir. Çünkü stres, mobbing bağlamında en tehdit edici unsurlardan biri olarak bilinmektedir. Şöyle ki; Hoel ve Salin mobbing ve stres arasında 
F.MAJIDLİ - G.BUDAK
ilişkiyi incelemek maksadıyla yaptığı çalışmada aşağıdaki sonuçlara varmışlardır (akt. Özler \& Mercan, 2009, s. 74):

> Çalışanların aşırı stresli ortamlarda yöneticilerle aralarında oluşan gerginlik nedeniyle mobbing eylemleri başlayabilmektedir.

> Çalışanların kendilerini aşırı stresli hissetmeleri mobbinge maruz kalmalarına ve hayal kırıklığı yaşamalarına neden olabilmektedir.

$>$ Çalışanların aşırı stresli ortamlarda örgütsel normları bırakmaları nedeniyle mobbing oluşabilmektedir.

Görüldüğü gibi stres ve mobbing arasında pozitif bir ilişki vardır. Ama bazı durumlarda iş ortamlarındaki monotonluk da mobbinge yol açabilmektedir. Bu durumlarda saldırganlar hep aynı işleri yapmaktan, ortamda oluşan sessizlikden rahatsız olabilmekte ve yeni bir heyecan yaratmak amaciyla mobbing uygulayabilmektedirler (Davenport vd., 2003, s. 48). Bu yüzden de İKY çalışanları örgüt içerisinde monotonluğu ve stresi önleyecek tedbirler almalıdirlar.

\subsection{Toplumsal Değerlerden Kaynaklanan Nedenler}

Nişancı'nın (2012, s. 1284) da belirttiği gibi “örgüt kültürü, içinde yer aldığ1 toplumun kültürüne göre bir alt kültürdür.” Bu nedenle de örgütsel sorunları incelerken önem vermemiz gereken unsurlardan biri de toplumsal değerlerdir. Toplumsal değerleri bütün nedenler üzerinde en çok etkide bulunan faktör olarak da değerlendirebiliriz.

2012 yılında yayınlanmış “Türkiye Değerler Atlası - 2012” (Esmer, 2012), siyasetten ekonomiye, dini değerlerden aile değerlerine kadar pek çok farklı alanda yapılan araştırmalar sonucunda Türk toplumunun birçok özelliklerini 
ortaya koymuştur. Yayınlanmış bu rapora dayanarak Türk toplumunun mobbinge neden olabilecek değerlerinden bazıları aşağıdaki gibi sıralanabilir:

Türkiye, \% 12 oranla dünyada kişilerarası güvenin en düşük olduğu ülkelerden biridir. - Kişilerarası güven olmadığı takdirde şüphe ortaya çıkmaktadır ki, daima birbirinden kuşkulanan iki insanın işbirliği sonunda birinin dışlanması ile sonlanabilir.

Türk toplumu Avrupa'nın ve hatta dünyanın en dindar ülkelerinden biridir. - Din her ne kadar bir inanç, bir felsefe olsa da, bir dine aşırı bağlılık, diğer dinden olan insanlara karşı ayrımcı davranışların sergilenmesine, önyargıya neden olabilecektir ki, bu durumda mobbinge yol açan özelliklerden biridir.

Siyasal ideoloji açısından Türkiye 47 Avrupa ülkesi içinde en sağda yer almaktadır. Bundan başka muhafazakarlık ölçeğine göre Türkiyenin ortalamas1 100 üzerinden 63'tür. - Bu durum da, Türk toplumunun muhafazakar olduğunu göstermektedir. Dine aşırı bağlılık durumunda olduğu gibi aşırı muhafazakarlık da ayrımcılığga ve dolayısıyla mobbinge neden olabilir.

$>\quad$ Cinsiyet eşitliği ölçeğinde Türkiye 60 ülke arasında 48. sırada yer almaktadır. Bundan başka kadınların bile \% 59'u "Kadın her zaman kocasına itaat etmeli”, fikrine katılmaktadır. - Türk toplumunda cinsiyet eşitsizliğinin mevcutluğunu ortaya koyan bu durum işletmelerde başarılı bir kadına karşı onun kariyer basamaklarında yükselişini önlemek adına mobbing uygulanmasına neden olabilir.

> Türkiye'de insanların \% 63’ü “Parlamento ve seçimlerle uğraşmak zorunda kalmayan güçlü bir lider iyi bir şeydir” görüşüne katılmaktadır ki, bu 


\section{F.MAJIDLI - G.BUDAK}

durumu toplumun çoğunluğunun kontrol edilme isteği, itaatkar bir ruh haline sahip olduğu gibi değerlendirebiliriz - Mağdurun bireysel özelliklerinden kaynaklanan nedenlerden söz ettiğimiz zaman belirttiğimiz gibi itaatkar kişilerin mobbinge maruz kalma riski daha fazladır.

\section{MOBBINGLE MÜCADELEDE FARKLILIKLARIN YÖNETIMİ ÖNEMİ}

Mobbing ve farklılıkların yönetimi konuları incelendiği zaman bu iki fenomenin iç içe geçtiği farkedilir. Mobbingle mücadele konusunda kilit noktalardan biri de farklılıkların yönetimidir. WorkSafe New Zealand tarafından yayımlanan mobbingle mücadele konulu bildiride örgütler açısından mobbingi engellemek için şirketteki farklılıkların tanınmasının ve desteklenmesinin gerekli olduğundan söz edilmektedir (WorkSafe New Zealand, 2014, s. 29). Şöyle ki; farklılıkların kabul görüldüğü ortamlarda anlaşmazlıklar, çatışmalar aza indirgenmekte, çokkültürlü bir iş ortamı yaratılmakta, çalışanların birbirlerine karşı saygılı davranmaları teşvik edilmektedir.

Ayrıca, yukarıda da görüldüğü gibi, Leymann'ın kritik olaylar olarak belirttiği mobbing sürecinin ilk aşaması, işletmede ortaya çıkmış anlaşmazlıkları, çatışmaları kapsamaktadır. Farklılıklar olgusunun iyi yönetilmediği ortamlarda bu gibi çatışmalardan kaçınmak ve dolayısıyla mobbingi önlemek imkansız olmaktadır. $\mathrm{Bu}$ nedenle de teorik olarak farklılıkların iyi yönetildiği örgütlerde mobbingin ortaya çıkma riskinin engelleneceği düşüncesindeyiz.

Farkl1lıkların bireysel etkilerinden söz ederken belirttiğimiz gibi farklılıklar konusu iyi yönetilmediği takdirde, bireyler psikolojik açıdan olumsuz yönde etkilenmektedirler. Böyle durumlarda bireyler kendilerine karşı olan en ufak 
haksızlıkları bile ayrımcılık olarak algılayarak kasten yapıldığını sanmakta ve bazı durumlarda kendilerini mobbing mağduru olarak hissedebilmektedirler. Bundan başka mobbinge neden olan farklı bireysel özelliklerle ilgili araştırmalar sayesinde elde edilen bulgular da işletmelerde iyi yönetilmeyen farklılıkların mobbinge yol açtığı fikrini desteklemektedir. Yine farklılıkların örgütsel sonuçlarından söz ederken, iyi bir farklılıklar yönetimi sürecinin takım çalışması açısından olumlu bir hava yarattığı vurgulanmaktadır ki, böyle bir pozitif ortamda mobbingin ortaya çıkma riski de daha zayıf olacaktır.

Acar ve Dündar (2008, s. 119) da mobbing ve demografik özellikler arasındaki ilişkiyi incelemek adına yaptıkları çalışmada mobbing ile eğitim seviyesi, yaş ve iş pozisyonu gibi arasında anlamlı bir ilişki olduğu sonucuna varmışlardır. Bu bulgular da işletmedeki içerisinde bilgi işçilerine önem veren işletmelerin farklılıkların yönetimi konusuna dikkat etmeleri gerektiğini göstermektedir. Çünkü iyi bir farklılık yönetimi sürecinin var olduğu işletmede ortam yumuşamakta, işyerinde stres azalmakta, insanların birbirlerine karşı olan tolerans duygusu artmakta, çatışmalar alevlenmeden önlenmektedir ki, bu durumların hepsi mobbing olayının ortaya çıkışını engellemektedir. Bunun yanı sıra mobbingi ortaya çıkaran örgütsel nedenler; olumsuz örgüt kültürü ve iklimi, kötü yönetim ve liderlik tarzları, farklı olmaktan kaynaklanan örgütsel çatışmalar sistematik bir şekilde yürütülen farkl1lıkların yönetimi stratejileriyle ortadan kalkacaktır ve bu durum da mobbingle mücadele kapsamında önemli adımlardan biri olarak görülebilir.

Mobbingin toplumsal nedenleri incelenirken görüldüğü gibi farklı dini inançlar, politik görüşler, cinsellik konuları ile ilgili toplumsal bir önyargı ve cinsiyet eşitsizliğinin mevcutluğu gibi farklılıkların yönetimi kapsamında ele 


\section{F.MAJIDLI - G.BUDAK}

alınan özellikler de mobbingi ortaya çıkaran unsurlardan bazılarıdır. Toplumun bir parçası olarak örgütlerin üzerlerine düşen görevlerden biri de bu gibi olumsuzlukları kendi bünyelerinde gerçekleştirdikleri farkındalık çalışmaları sayesinde minimize etmek, örgüt üyelerinin bu gibi önyargılardan kurtulmasını sağlamaktır. Çünkü bu durumda hem örgüt içinde, hem de toplumsal çerçevede bireylerin bir birlerine karşı olan saygısı, empati duyguları artabilir ki, bu da daha sağlıklı bir toplumsal ortamın yaratılmasına neden olacaktır. Yukarıda da vurgulandığı gibi bu gibi sonuçlara varmak isteyen örgütler farklılıkların yönetimi stratejilerini başarılı şekilde uygulamaya büyük önem göstermelidirler.

\section{MOBBINGLE MÜCADELEDE FARKLILIKLARIN YÖNETIMİ STRATEJILERI}

Hatırlanacağı üzere "Bütünleştirilmiş Etkili Farklılık Yönetimi Modeli”nden söz ettiğimiz zaman CEO'ların farklılık yönetimi sürecinde önemli sorumluluklar üstendiğini belirtmiştik ki, bu da net olarak farklılıkların stratejik olarak yönetilmesinin ne kadar gerekli olduğunun önemli bir işaretidir. Çatışmazlıkların çözümlenmesi, insana değer verilmesi, olumlu örgüt kültürünün oluşturulması bu sorumluluklar kapsamında ele alınmaktadır ki, iyi yönetim ve liderlik tarzı sergileyen CEO'lar; yöneticilerden kaynaklanan mobbingi de engellemiş olacaklardır. CEO'ların önderliği ile uygulanan farklılıkların yönetimi modelinde en büyük görev İK departmanının üzerine düşmektedir. Gilbert vd. de oluşturdukları bu modelde farklılıkların yönetimi konusunun İK departmanının çalışma alanına girdiğini belirtmekte ve farklılık faaliyetlerinin bir sonucu gibi psikolojik uyumsuzlukta azalmanın, çalışanlar arasında bütünleşmenin ortaya çıktığını vurgulamaktadırlar. 
Dokuz Eylül Üniversitesi İktisadi ve İdari Bilimler Fakültesi Dergisi

Cilt:33, Sayl:1, Yll:2018, ss. 129-161

$\mathrm{Bu}$ modelden yola çıkarak, işletmelerin İK departmanlarının, yaratıcılık olgusunu olumlu yönde etkileyen, örgüt imajına olumlu yönde katkı yapan farklılıkların, bu gibi faydalarını göz önünde bulundurarak işgücü planlanması aşamasında belirli iş alanları için farklı özelliklere sahip çalışanların ne gibi avantajlar sağlayacağı yönünde araştırmalar yürütmesi ve genel olarak bu konuya dikkat etmesi gerektiğini önermekteyiz. Peki farklılıkları kendi bünyesinde bulunduran işletmelerin İK departmanları hem farklılıklardan dolayı hem de diğer nedenlerden dolayı ortaya çıkacak mobbing eylemlerini uygulayabilecekleri hangi stratejiler vasıtasıyla önleyebilirler?

Farklılıkların yönetimi ve mobbingle ilgili araştırdığımız çeşitli kaynaklardan yola çıkarak işletmelerin ve özellikle de İK departmanlarının mobbingle mücadele kapsamında uygulayabilecekleri stratejiler Tablo 3.'de belirtilmektedir:

Tablo 3. Mobbingle Mücadelede Farklılıkların Yönetimi Stratejileri

\begin{tabular}{|c|c|}
\hline Stratejiler & Ayrıntılar \\
\hline $\begin{array}{l}\text { Farkındalık } \\
\text { Faaliyetleri }\end{array}$ & $\begin{array}{l}\text { Farklılıklarla ilgili eğitimler vermek, farklılıkların işletme ve örgüt } \\
\text { kültürüne katacağı avantajları anlatmak } \\
\text { Mobbingin ne olduğunu, hangi faaliyetleri kapsadığını açık şekilde } \\
\text { belirtmek } \\
\text { İşletmelere değer katan farklılıklarla ilgili örnek olaylar anlatarak işçilerin } \\
\text { konuya daha da hakim olmasını sağlamak }\end{array}$ \\
\hline $\begin{array}{l}\text { Mentörlük } \\
\text { Faaliyetleri }\end{array}$ & $\begin{array}{l}\text { Farklı özelliklere sahip kişiler istihdam edildiği günden itibaren } \\
\text { kendilerine belli etmeksizin tayin edilmiş mentörler tarafından yakından } \\
\text { izlenilmelidir. } \\
\begin{array}{l}\text { Gösterdikleri faaliyetler ve aynı zamanda karşılaştıkları herhangi } \\
\text { çatışmalarla ilgili mentörlerden düzenli şekilde rapor alınmalıdır. }\end{array}\end{array}$ \\
\hline $\begin{array}{l}\text { Mobingle ilgili } \\
\text { Bildiri } \\
\text { Hazırlanması ve } \\
\text { Dağıtılması }\end{array}$ & $\begin{array}{l}\text { Mobbing davranışları net bir şekilde belirtilmeli } \\
\text { Mobbing uygulayıcılarının alacakları cezalar belirtilmeli } \\
\text { Mağduriyyetin giderilmesi yolları belirtilmeli }\end{array}$ \\
\hline
\end{tabular}




\section{F.MAJIDLI - G.BUDAK}

\begin{tabular}{|c|c|}
\hline & $\begin{array}{l}\text { İşletme içerisinde mobbing sorunu ile ilgili yetkili kişinin kim olduğu } \\
\text { belirtilmeli } \\
\text { Mağdurların izlemesi gereken adımlar açık şekilde belirtilmeli } \\
\text { Bildiri bütün çalışanlara dağıtılarak her biri tarafından okunup } \\
\text { imzalanması sağlanmalı }\end{array}$ \\
\hline $\begin{array}{c}\text { Farklılıklarla } \\
\text { ilgili Bildiri } \\
\text { Hazırlanması ve } \\
\text { Dağıtılması }\end{array}$ & $\begin{array}{l}\text { Ayrımcılık içeren davranışları açık şekilde belirtmek } \\
\text { Ayrımcılık sergileyen bireylerin alacakları cezaları net bir şekilde } \\
\text { belirtmek } \\
\text { İşletme içerisinde ayrımcılık konusu ile ilgili yetkili kişinin kim olduğu } \\
\text { belirtilmeli } \\
\text { Mağdurların izlemesi gereken adımlar açık şekilde belirtilmeli } \\
\begin{array}{l}\text { Bildiri bütün çalışanlara dağıtılarak her biri tarafından okunup } \\
\text { imzalanması sağlanmalı }\end{array}\end{array}$ \\
\hline $\begin{array}{c}\text { Şirket İçi } \\
\text { Araştırmalar }\end{array}$ & $\begin{array}{l}\text { İşyerinde ayrımcılığın varlığıyla ilgili araştırma yapmak } \\
\text { Şirket için en uygun mobbing ölçeğini belirlemek } \\
\text { Belirli zaman aralıklarıyla (örn.,her üç ayda bir) mobbingin varlığıyla ilgili } \\
\text { anket çalışması yürütmek } \\
\text { Anket sonuçlarını değerlendirerek gözlemlenen sorunların ortadan } \\
\text { kalkması için stratejiler belirlemek }\end{array}$ \\
\hline $\begin{array}{l}\text { Çatışmaları } \\
\text { Yönetmek }\end{array}$ & $\begin{array}{l}\text { Çatışma Yönetimi ile ilgili eğitimler vermek, çalışanların sorun çözme } \\
\text { yeteneğini geliştirmek } \\
\text { Çatışmaların nedenini inceleyip durum değerlendirmesi yapmak } \\
\text { Çatışma tarafları ile görüşerek müzakereler teşkil etmek } \\
\text { Müzakerelerin çözümlenmesi için uygun ortamın sağlanmasına çalışmak } \\
\text { Müzakereli sonuçlandırmak ve sonuçları raporlayarak üst yönetime bilgi } \\
\text { vermek }\end{array}$ \\
\hline $\begin{array}{c}\text { Mobbing ve } \\
\text { Ayrımcilıkla ilgili } \\
\text { Şikayetlerin } \\
\text { Değerlendirilmesi }\end{array}$ & $\begin{array}{l}\text { Bütün şikayetleri gözardı edilmeyecek şekilde en kısa zamanda detaylı } \\
\text { olarak incelemeli } \\
\text { Şikayet tarafları (varsa şahitler dahil) ile bire bir görüşmeler geçirmeli } \\
\text { Şikayetlerin sonuçlandırıldıktan sonra suç ve cezalar belirtilmeli ve üst } \\
\text { yönetime sonuçlarla ilgili detaylı şekilde bilgi verilmeli }\end{array}$ \\
\hline
\end{tabular}




\section{SONUÇ}

Farklılıkların yönetimi olgusu ilk başlarda ABD'de sadece siyah ve beyaz ayrımcılığını önlemek için ortaya çıkan bir kavram olsa da sonradan bu kavram genişlemiş ve toplumdaki 1rk, cinsiyet, etnik köken, yaş, cinsel yönelim, fiziksel görünüş, engellilik, eğitim düzeyi, dini inançlar,coğrafi konum, medeni durum, gelir düzeyi, iletişim tarzları ve diğer değişik özellikleri de kapsar hale gelmiştir.

Günümüzde neredeyse bütün işletmeler kendi bünyesinde bir farklılık yelpazesi bulundurmaktadır. Yukarıdaki bölümlerde farklılıkların iyi yönetilmediği zaman hem bireysel, hem örgütsel, hem de toplumsal açıdan olumsuz yönde ortaya çıkan etkilerinden söz etmiştik. Şöyle ki; farkl1lıklar iyi yönetilmediği takdirde bu durum şirket içinde işgücü devri ve işe gelmeme oranında, maliyetlerde artış, kötü şirket imajı, yaratıcılık ve yenilik düzeyinde azalma, katılık ve bu gibi bir takım olumsuz örgütsel sonuçlara, bireysel açıdan fiziksel ve psikolojik sorunlara, toplumsal açıdan çatışmalara, düzensizliğe neden olabilir. Farklılıkların diğer olumsuz sonuçlarından biri de; mobbingdir. Biz bu yazında sadece işyerinde ortaya çıkan mobbingi incelemeye çalıştık. Ancak şunu da söylemeden geçemeyiz; mobbing insanların faaliyet gösterdikleri, bir arada bulundukları bütün ortamlarda ortaya çıkabilir. Mobbingi önleyen ana nedenlerden biri de insanların birbirlerini anlaması, birbirlerine tolerans göstermesi, empati kurabilme becerilerinin gelişmesidir. Farklılıkların yönetimi de tam olarak bu gibi olguları desteklemektedir.

$\mathrm{Bu}$ nedenle de biz günümüz işletmelerinde farklılıklar konusuna kayıtsız kalınmamasını, bu yönetim sürecinin ve farklılıkların yönetimi stratejilerinin kendi bünyelerinde uygulanmasını tavsiye etmekteyiz.

Özellikle de hızlı bir gelişmenin ve acımasız bir rekabetin var olduğu günümüz dünyasında işletmeler açısından avantaj sağlayan farklılıkların yönetimi, önemli bir 


\section{F.MAJIDLI - G.BUDAK}

işletme stratejisidir. Şirketi içten yiyen mobbing gibi bir canavarı da büyük oranda etkisizleştirmeyi başaran, mobbing risklerini aza indirgeyen bir işletme stratejisi olarak farkl11ıkların yönetimi, şirket içinde pozitif bir ortam yaratarak, insanlara değer veren örgüt kültürleri sayesinde hem toplumun, hem de kendi çalışanlarının saygısını kazanacak, çalışanların işe bağımlılık düzeyini yükseltecek ve böylece çalışanlar kendilerini işletmenin bir parçası olarak göreceğinden daha verimli çalışmaya başlayacaklardır. Başarının bir kaç anahtarından biri olan farklılıkların yönetimi, detaylı bir şekilde öğrenilip uygulandığı zaman şirketler için önemli faydalara neden olabilir. Tersi bir durumda meydana gelebilecek olumsuzluklar, ayrımcılık artabileceğinden işletmeye büyük zararlar verebilir.

Farklılıkların yönetimi, stratejik bir karardır. Bu nedenle de tüm örgüte, uzun vadede kalıcılık yaratacak politikalarla yayılacak biçimde uygulanmalıdır.

\section{KAYNAKÇA}

ACAR, A. B., DÜNDAR, G. (2008), "İşyerinde psikolojik yıldırmaya (mobbing) maruz kalma sıklığı ile demografik özellikler arasındaki ilişkinin incelenmesi", İstanbul Üniversitesi İsletme Fakültesi Dergisi, 37(2), 111-120.

ANÇEL, G. (2012), "İşyerinde Mobbing: Mağdurun Kişilik Yapısı ve Karpman`ın Üçlü Draması", Ankara Sağlık Bilimleri Dergisi, 1(2), 89-100.

BARUTÇUGİL, İ. (2011), Kültürlerarası Farklılıkların Yönetimi, Kariyer Yayıncılık, İstanbul.

BUDAK, G. (2013), Yetkinliğe Dayalı Insan Kaynakları Yönetimi (2. Baskı), Barış Yayınları, İzmir.

ÇOBANOĞLU, Ş. (2005), Mobbing işyerinde duygusal saldırı ve mücadele yöntemleri, Timaş Yayınları, İstanbul.

DAVENPORT, N., SCHWARZ, R. D., ELLIOTT, G. P. (2003), Mobbing: İsyerinde duygusal taciz, (Çev. O. C. Önertoy), Sistem Yatıncılık, İstanbul. 
Dokuz Eylül Üniversitesi İktisadi ve İdari Bilimler Fakültesi Dergisi

Cilt:33, Sayl:1, Yll:2018, ss. 129-161

EĞİNLİ, A. T. (2009), "Örgütsel Bağlılığın Geliştirilmesinde Farklılık Yönetimi", Yayınlanmış Doktora Tezi, Ege Üniversitesi, Sosyal Bilimler Enstitüsü, Halkla İlişkiler ve Tanıtım Anabilim Dalı, İzmir.

EINARSEN, S. (1999), "The nature and causes of bullying at work", International journal of manpower, 20(1/2), 16-27.

ERTÜRK, A. (2013), "Yıldırma Davranışları, Nedenleri ve Sonuçları (Mobbing Behaviors, Causes and Results)" BARTIN ÜNİVERSITESI EĞITIIM FAKÜLTESİ DERGISII, 2(1), 146-169.

ESMER, Y. (2012), "Türkiye Değerler Atlası 2012", http://www.benimicininsanhaklari.org/wp-content/uploads/05-Turkey-ValuesStudy-2012-Turkiye-Degerler-Atlasi-2012.pdf, (10.08.2016)

FOX, S., STALLWORTH, L. E. (2005), "Racial/ethnic bullying: Exploring links between bullying and racism in the US workplace", Journal of Vocational Behavior, 66(3), 438-456.

GİLBERT, J. A., STEAD, B. A., IVANCEVİCH, J. M. (1999), "Diversity Management: A New Organizational Paradigm", Journal of Business Ethics, 21(1), 61-76.

HENRY, O., EVANS, A. J. (2007), "Critical review of literature on workforce diversity”, African Journal of Business Management, 72-76.

HOEL, H., GLASØ, L., HETLAND, J., COOPER, C. L., EINARSEN, S. (2010), "Leadership styles as predictors of self-reported and observed workplace bullying", British Journal of Management, 21(2), 453-468.

HUBBARD, E. E. (2004), The Managers Pocket Guide to Diversity Management, HRD PRESS, Amherst, Massachusetts.

JAMIESON, D., \& O'MARA, J. (1991), Managing Workforce 2000: Gaining The Diversity Advantage, Wiley. 


\section{F.MAJIDLİ - G.BUDAK}

KARAVARDAR, G. (2009), "İş Yaşamında Psikolojik Yıldırma ve Psikolojik Yıldırmaya Direnç Gösteren Kişilik Özellikleri ile İlişkisi", Yayınlanmış Doktora Tezi, T. C, İstanbul Üniversitesi, Sosyal Bilimler Enstitüsü, İşletme Anabilim Dalı, İnsan Kaynakları Yönetimi Bilim Dalı, İstanbul.

LEYMANN, H. (1990), "Mobbing and psychological terror at workplaces", Violence and victims, 5(2), 119-126.

LEYMANN, H. (1996), "The content and development of mobbing at work", European journal of work and organizational psychology, 5(2), 165184.

MATTHIESEN, S. B., EINARSEN, S. (2001), "MMPI-2 configurations among victims of bullying at work", European Journal of work and organizational Psychology, 10(4), 467-484.

MEMDUHOĞLU, H. B. (2007), "Yönetici ve öğretmen görüşlerine göre Türkiye'de kamu liselerinde farklılıkların yönetimi", Yayınlanmış Doktora Tezi, Ankara Üniversitesi, Eğitim Bilimleri Enstitüsü, Ankara.

NişANCI, Z. N. (2012), "Toplumsal kültür-örgüt kültürü ilişsisi ve yönetim üzerine yansımaları", Journal of Life Sciences, 1(1), 1279-1293.

ÖZLER, D. E., MERCAN, N. (2009), Yönetsel ve Örgütsel Açıdan Psikolojik Terör - Mobbing, Detay Yayıncılık, Ankara.

PEguero, A. A., WillíAMS, L. M. (2013), "Racial and ethnic stereotypes and bullying victimization", Youth \& Society, 45(4), 545-564.

ROHLAND, L. (2015), "Mobbing", Salem Press Encyclopedia, Ipswich, MA. http://eds.b.ebscohost.com/eds/detail/detail?sid=0bc65e78-a4f1-42c9beda-

a11a99cdfeb6\%40sessionmgr106\&vid=1\&hid=113\&bdata=JnNpdGU9ZWRz LWxpdmUmc2NvcGU9c210ZQ\%3d\%3d\#AN=100259274\&db=ers, (13.07.2016). 
ROSADO, C. (2006), "What do we mean by "managing diversity"", EdChange. http://www.edchange.org/multicultural/papers/rosado_ managing_diversity.pdf, (12.04.2016).

SÜRGEVİL, O. (2010), Çalışma Yaşamında Farklılıkların Önemi, Nobel Yayınları, Ankara.

THOMAS, R. R. (2011), "The management of workforce diversity: A continuing evolution" Employment Relations Today, 38(3), 1 -9.

TUTAR, H. (2015), Mobbing (Nedenleri ve Başa Çıkma Stratejileri: Kuramsal Yaklaşım), Detay Yayıncılık, Ankara.

WORKSAFE NEW ZEALAND. (2014). "Preventing and Responding to Workplace Bullying: Best Practices Guidelines", Publications of the University of Nebraska Public Policy Center, Wellington, http://digitalcommons.unl.edu/cgi/viewcontent.cgi ?article=1160\&context=pub licpolicypublications, (30.03.2017).

ZAPF, D. (1999), "Organisational, work group related and personal causes of mobbing/bullying at work", International journal of manpower, 20(1/2), 70-85.

ŽUKAUSKAS, P., VVEINHARDT., J. (2009), "Socio-demographic characteristics of mobbing and discrimination in employee relations", Transformations in Business \& Economics, 8(3).

https://en.wikipedia.org/wiki/Reverse_discrimination\#cite_noteSchaefer2008-3, (03.03.2016).

http://www.goc.gov.tr/icerik6/gecici-koruma_363_378_4713_icerik, (18.04.2017). 